\title{
Servicii medicale integrate pentru pacienții coinfectați HIV/NHC din România ce provin din populațiile marginalizate - modelul Proiectului HepCare Europe implementat la Spitalul „Dr . Victor Babeș“ din București
}

\author{
Irina lanache' ${ }^{1}$, Ştefan Lazăr ${ }^{1}$, Ionuț Popa ${ }^{1}$, Alma Kosa ${ }^{1}$, Anca Luca ${ }^{1}$, \\ Ioan Petre ${ }^{1}$, Simin-Aysel Florescu ${ }^{1,2}$, Cristiana Oprea ${ }^{1,2}$ \\ ${ }^{1}$ Spitalul Clinic de Boli Infecţioase şi Tropicale „Dr. Victor Babeş“, Bucureşti, România \\ 2Universitatea de Medicină şi Farmacie „Carol Davila“, Bucureşti, România
}

\begin{abstract}
REZUMAT
Background. Proiectul HepCare Europe, cofinanţat de Comisia Europeană, a avut ca scop crearea şi implementarea unui model de management al VHC (screening, evaluare şi tratament) adresat pacienţilor ce provin din populaţiile vulnerabile. Ideea de bază a proiectului a fost creşterea accesului acestor pacienţi la servicii medicale integrate, prin implicarea cadrelor medicale din comunitate. Scopul acestui studiu a fost să evalueze caracteristicile socio-demografice şi clinice ale pacienţilor coinfectaţi HIV/VHC comparativ cu cei monoinfectaţi cu VHC înrolaţi în Proiectul HepCare Europe, în cadrul Spitalului Clinic de Boli Infecţioase şi Tropicale „Dr. Victor Babeş“ din Bucureşti.

Metode. Studiu prospectiv efectuat la pacienţii cu anticorpi anti-VHC pozitivi (prin teste rapide orale), ce au fost evaluaţi la Spitalul „Dr. Victor Babeş“ din Bucureşti, România (SVB), în perioada aprilie 2016 - aprilie 2019. Caracteristicile socio-demografice şi clinice ale pacienţilor au fost comparate în funcţie de statusul de coinfectat HIV. Analiza statistică a datelor s-a realizat folosind programul SPSS versiunea 20.0.

Rezultate. Screening-ul pentru hepatita cronică cu virus C s-a realizat la 525 de pacienţi, dintre care 230 $(43,8 \%)$ au avut rezultat pozitiv. Majoritatea erau tineri, de sex masculin $(85,2 \%)$ şi utilizatori de droguri injectabile (92,2\%). 168 de pacienţi $(73,0 \%)$ au fost evaluaţi la spital, din care $41,6 \%$ erau coinfectaţi HIV. Evaluarea gradului de fibroză hepatică s-a realizat pentru $82,1 \%$ dintre pacienţi, aproape o treime fiind identificaţi cu fibroză hepatică avansată $(27,5 \%)$. ARN-VHC în plasmă a fost efectuat pentru jumătate din pacienţii luaţi în evidenţă, 80,9\% din aceştia având încărcătură virală detectabilă. 24 de pacienţi au iniţiat tratamentul cu agenţi antivirali direcţi, din care 22 au obţinut răspuns viral susţinut, iar 2 au fost nonresponderi (utilizatori de droguri infectaţi cu genotip 3 ce nu au primit tratament cu regim pangenotipic). Infecţia HIV s-a asociat cu lipsa locuinţei $(p<0,0001)$, consumul de droguri injectabile $(p=0,001)$, consumul de etnobotanice în asociere cu opioidele $(p<0,0001)$, utilizarea de ace la comun $(p<0,0001)$ sau consumul de alcool $(p<0,0001)$.

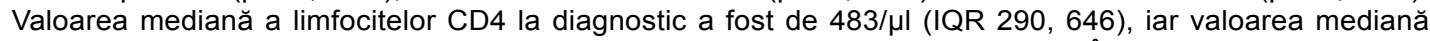
a încărcăturii virale HIV în plasmă a fost de $2.74 \log 10$ copii/ml (IQR 1,27, 4,67). Încărcătura virală VHC în plasmă a fost semnificativ mai mare la pacienţii coinfectaţi HIV/VHC $(p=0,047)$.

Concluzii. Coinfecţia HIV/VHC a fost frecventă la pacienţii ce provin din populaţiile vulnerabile. Infecţia HIV a fost asociată cu multipli factori de risc şi încărcătură virală VHC plasmatică mai ridicată. Barierele socio-economice şi accesul redus la tratamente pangenotipice cu agenţi antivirali direcţi (DAA) au limitat semnificativ iniţierea tratamentului la aceşti pacienţi. Acesta este primul studiu pilot din România despre managementul pacienţilor cu hepatită C care provin din populaţiile cheie.
\end{abstract}




\section{BACKGROUND}

Hepatita cronică cu virus C (VHC) reprezintă una dintre cele mai importante cauze de morbiditate şi mortalitate la nivel mondial, ce se complică deseori cu afecţiuni severe, cum sunt ciroza hepatică şi carcinomul hepato-celular (CHC). Se estimează că aproximativ 3\% din populaţia lumii este afectată de infecţia cu VHC $(1,2)$.

Rapoartele disponibile la nivel national în România indică o sero-prevalenţă a VHC de 3,23\%, $2,72 \%$ dintre pacienţi având şi viremie detectabilă. Studiile efectuate înainte de 2009 au arătat că genotipul cel mai frecvent în ţara noastră era genotipul 1 (99\%), mai ales subtipul 1b, cu transmiterea cea mai frecventă prin transfuzii sangvine înainte de 1993, când nu se efectua screening-ul infecţiilor cu transmitere parenterală, sau prin proceduri medicale nesterile la finalul anilor 1980. Epidemiologia hepatitei cu virus C în România s-a modificat în ultimii ani, pe fondul creşterii semnificative a consumului de droguri injectabile, cu răspândirea de noi genotipuri VHC. În paralel cu consumul de opioide, drogurile psihoactive noi, local cunoscute sub numele de ,etnobotanice“, au fost utilizate tot mai des, fiind mai ieftine şi mai accesibile pentru utilizatori. Aceste droguri sunt înalt adictive şi au un timp de înjumătăţire scurt, motiv pentru care necesită până la 10-20 de administrări pe zi $(1,3,4)$.

Răspândirea epidemiilor HIV şi VHC în rândul utilizatorilor de droguri injectabile din România a fost favorizată de utilizarea tot mai frecventă a drogurilor psihoactive pe cale parenterală. Acest lucru a fost, de asemenea, un factor de risc pentru diseminarea în populaţia generală a genotipurilor VHC diferite de $1 \mathrm{~b}$, cu rate de răspuns variabile la tratamentul cu agenţi antivirali cu acţiune directă. Comparativ cu monoinfecţia VHC, coinfecţia HIV/ VHC este asociată cu fibroză hepatică accelerată şi rate crescute de decompensare hepatică (1,3-5).

Utilizatorii de droguri injectabile încă reprezintă o provocare majoră pentru sistemul de sănătate românesc din cauza comportamentelor lor la risc, a afecţiunilor neuro-psihiatrice, a comorbidităţilor multiple şi a problemelor sociale (lipsa locuinţei, a documenteleor de identitate sau a asigurării de sănătate).

HepCare Europe este un proiect cofinanţat de Comisia Europeană, al cărui scop a fost să creeze şi să implementeze un model de management VHC (testare, evaluare şi tratament) pentru pacienţii ce provin din populaţiile cheie, prin mobilizarea cadrelor medicale în comunitate şi creşterea accesului acestor pacienţi la servicii medicale primare şi secundare integrate. Acest consorţiu este format din 5 instituţii ce provin din 4 ţări (Irlanda, Marea Britanie, Spania şi România) (6).

Proiectul a fost structurat pe 5 pachete de lucru (WP) interconectate, create cu scopul de a optimiza managementul hepatitei cronice cu virus $\mathrm{C}$ la pacienţii ce provin din grupurile marginalizate (Figura 1) (5).

1. HepCheck - screening-ul anticorpilor antiVHC folosind teste rapide orale (OraQuick)

Testarea VHC s-a realizat folosind teste point-of care, cu ajutorul lucrătorilor sociali din ONG-urile ce activează în comunitate, al personalului care activează în adăposturi de noapte, penitenciare, centre de tratament de substituţie cu metadonă sau al medicilor de familie. Toţi pacienţii testaţi au fost înrolaţi în baza de date a proiectului HepCare şi au oferit informaţii despre stilul lor de viaţă, factori de risc pentru transmiterea VHC sau istoricul lor medical.

2. HepLink - evaluarea, stadializarea și tratamentul pacienților prin servicii medicale primare și secundare integrate

Pacienţii cu rezultat pozitiv la screening-ul efectuat în cadrul pachetului de lucru HepCheck au fost îndrumaţi către medicii specialişti de boli infecţioase pentru stadializarea fibrozei hepatice şi evaluarea viremiei VHC. La pacienţii eligibili s-a iniţiat tratament cu agenţi antivirali direcţi (DAA). Toţi pacienţii care au accesat serviciile medicale de specialitate au fost înscrişi în baza de date HepLink, cu informaţii despre rezultatul investigaţiilor efectuate.

\section{HepEd - educație interprofesională}

$\mathrm{Au}$ fost organizate mai multe cursuri educaţionale VHC cu scopul de a oferi informaţii actualizate despre managementul VHC la pacienţii ce provin din populaţiile marginalizate. Acest pachet de lucru s-a adresat personalului medical, în mod special medicilor de familie, dar şi altor specialişti (boli infecţioase, psihiatrie, gastroenterologie, farmacologie etc.), asistente, lucrători sociali şi psihologi. Eficacitatea acestor cursuri a fost evaluată prin chestionare înainte şi după curs. 


\section{HepFriend - programe de peer support}

Acest pachet s-a bazat pe recrutarea persoanelor din comunitate, cu stil de viaţă asemănător cu al pacienţilor cărora se adresează acest proiect, şi a avut ca scop pregătirea şi suportul acestora pentru a se implica în procesul de îmbunătăţire a comunicării dintre pacienţi şi personalul medical. Au fost organizate, de asemenea, sesiuni de peer support, $\mathrm{cu}$ scopul de a creşte aderenţa la tratament.

5. HepCost - evaluarea cost-eficienței imple$\underline{\text { mentării modelului prezentat }}$

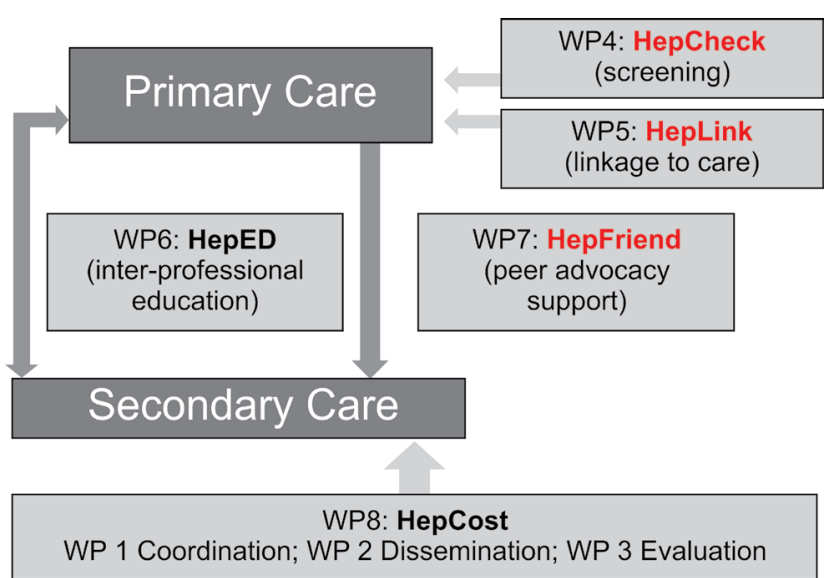

FIGURA 1. Pachetele de lucru (WP) din cadrul Proiectului HepCare Europe

Scopul acestui studiu a fost să evalueze caracteristicile socio-demografice şi clinice ale pacienţilor coinfectaţi HIV/VHC care au fost înrolaţi în Proiectul HepCare Europe în clinica din Bucureşti şi să îi compare cu pacienţii monoinfectaţi cu VHC.

\section{METODE}

Am realizat un studiu prospectiv la pacienţii cu rezultat pozitiv la screening-ul anticorpilor antiVHC (folosind teste rapide orale), o parte dintre ei fiind ulterior îndrumaţi şi evaluaţi la Spitalul Clinic de Boli Infecţioase şi Tropicale „Dr. Victor Babeş“ din Bucureşti, în perioada aprilie 2016 - aprilie 2019. Caracteristicile socio-demografice şi clinice ale pacienţilor evaluaţi au fost comparate în funcţie de statusul coinfecţiei HIV.

Screening-ul VHC a fost efectuat cu teste rapide orale (OraSure Technologies OraQuick HCV), în 9 centre ce acordă servicii medicale sau sociale pacienţilor din populaţia ţintă ( 3 adăposturi de noapte, 3 centre de tratament de substituţie cu metadonă, 2 penitenciare şi o unitate spitalicească), precum şi la cabinetele medicilor de familie sau de către personalul ONG-urilor ce au mers în comunitate şi au efectuat campanii de screening. Pacienţii testaţi au primit consiliere pre- şi postscreening, respectiv informaţii despre proiect şi scopurile acestuia. Fiecare pacient a semnat un formular de consimţământ, a completat un chestionar despre stilul personal de viaţă şi istoricul medical şi a oferit date de contact. Pacienţii cu rezultat pozitiv la testul de screening au fost programaţi să vină la Spitalul Victor Babeş pentru evaluare şi tratament.

Infecţia VHC a fost confirmată prin testarea anticorpilor anti-VHC (ELISA - enzyme linked immunosorbent assays), respectiv a încărcăturii virale VHC în plasmă. Gradul de fibroză hepatică a fost evaluat prin FibroScan sau FibroMax, un scor METAVIR mai mare de $9 \mathrm{kPa}$ fiind sugestiv pentru fibroză avansată.

Analiza statistică a datelor s-a realizat folosind SPSS vs. 20.0. Datele categorice au fost comparate prin Chi-square sau Fischer's exact test, iar variabilele continue au fost comparate prin t-test sau OneWay Anova test. Valorile $\mathrm{p}<0.05$ au fost sugestive pentru diferenţe cu semnificaţie semnificativă.

\section{REZULTATE}

Pe parcursul acestui studiu, 525 de pacienţi au fost testaţi pentru $\mathrm{VHC}$ cu teste rapide orale, dintre care 228 (43.3\%) erau utilizatori de droguri injectabile. $230 / 525$ (43.8\%) dintre pacienţii testaţi au obţinut rezultat pozitiv. Proporţia pacienţilor cu anticorpi anti-VHC pozitivi a fost semnificativ mai mare la pacienţii testaţi în spitalul de boli infecţioase şi în centrele de tratament de substituţie cu metadonă, comparativ cu cei testaţi în penitenciar sau în adăposturile de noapte $(\mathrm{p}<0.0001)$ (Figura 2).

Majoritatea pacienţilor seropozitivi VHC erau de sex masculin 85.2\% (196/230), cu vârsta mediană 35 de ani (IQR 31, 39). Aproape toţi aveau istoric de consum injectabil de droguri, iar o treime consumau alcool (Tabelul 1).

168/230 (73,0\%) de pacienţi au fost îndrumaţi către spitalul de boli infecţioase pentru evaluare, 41,6\% (70/168) dintre aceştia fiind coinfectaţi HIV. Infecţia HIV a fost mai frecvent asociată cu lipsa locuinţei ( $p<0,0001)$, consumul injectabil de droguri $(p=0,001)$, utilizarea drogurilor etnobotanice în combinaţie cu opioidele $(\mathrm{p}<0,0001)$, utilizarea 


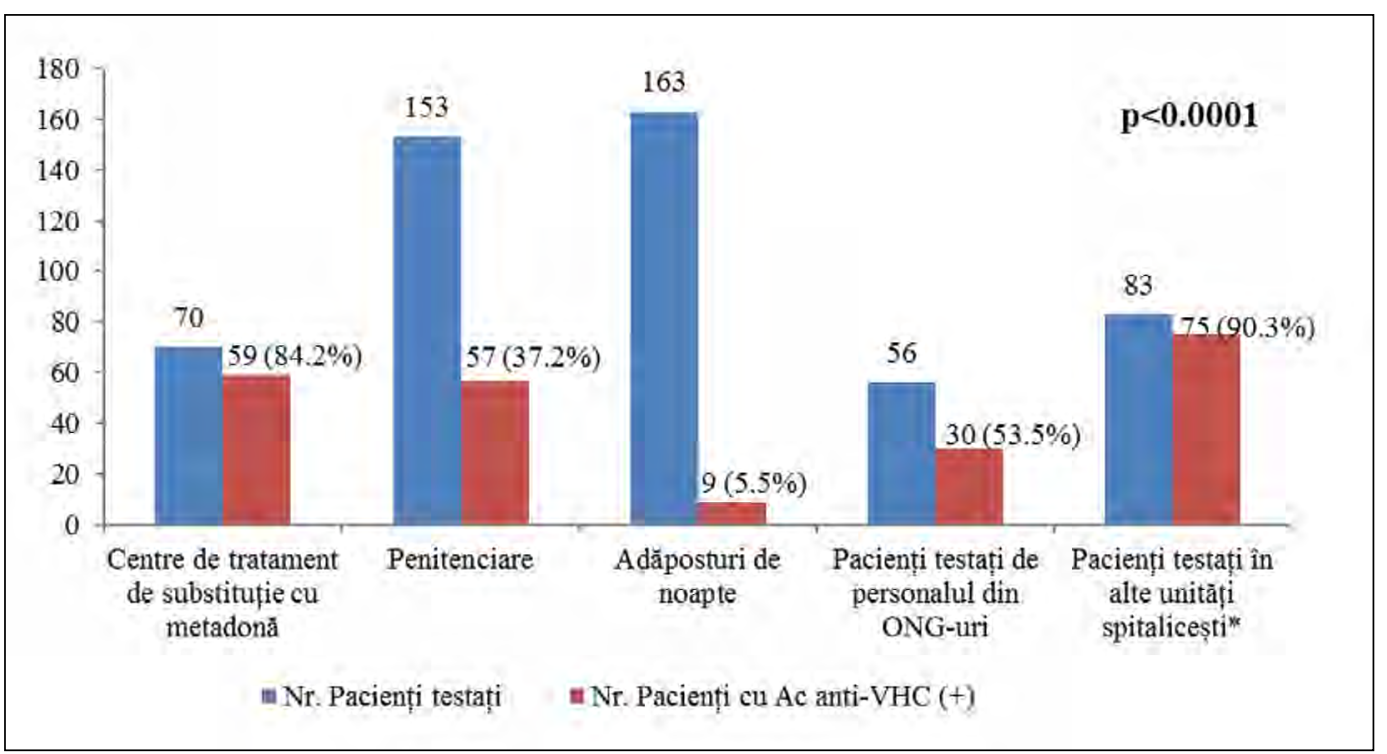

FIGURA 2. Proporția pacienților cu anticorpi anti-VHC pozitivi - comparație între centrele unde s-a efectuat screening-ul VHC

*în mod special utilizatori de droguri injectabile testați în spitalul de boli infecțioase

TABELUL 1. Caracteristici sociale ale pacienților ce au accesat serviciile de sănătate comparație în funcție de statusul infecției HIV

\begin{tabular}{|l|c|c|c|c|c|}
\hline & & $\begin{array}{c}\text { Total } \\
\mathbf{n = 1 6 8}\end{array}$ & $\begin{array}{c}\text { HIV (+) } \\
\mathbf{n = 7 0}\end{array}$ & $\begin{array}{c}\text { HIV (-) } \\
\mathbf{n = 9 8}\end{array}$ & $\begin{array}{c}\text { valoare } \\
\boldsymbol{p}\end{array}$ \\
\hline Absența locuinței & $\mathrm{n}(\%)$ & $61(36,3)$ & $37(52,8)$ & $24(24,4)$ & $<0,0001$ \\
\hline Istoric de detenție & $\mathrm{n}(\%)$ & $89(52,9)$ & $42(60,0)$ & $47(47,9)$ & 0,83 \\
\hline Tratament de substituție cu metadonă & $\mathrm{n}(\%)$ & $85(50,5)$ & $32(45,7)$ & $53(54,0)$ & 1,81 \\
\hline Utilizatori de droguri injectabile & $\mathrm{n}(\%)$ & $155(92,2)$ & $70(100)$ & $85(86,7)$ & 0,001 \\
\hline Utilizare de ace la comun & $\mathrm{n}(\%)$ & $82(48,8)$ & $51(72,8)$ & $31(31,6)$ & $<0,0001$ \\
\hline $\begin{array}{l}\text { Tipul de drog } \\
\text { Heroină } \\
\text { Etnobotanice }\end{array}$ & $\mathrm{n}(\%)$ & $30(17,8)$ & $7(10,0)$ & $24(24,4)$ & \\
Consum mixt & & $73(33,9)$ & $16(22,8)$ & $42(42,8)$ & $<0,0001$ \\
\hline Consum de alcool & $\mathrm{n}(\%)$ & $67(39,8)$ & $51(72,8)$ & $24(24,4)$ & \\
\hline
\end{tabular}

de ace la comun $(\mathrm{p}<0.0001)$ şi consum de alcool ( $\mathrm{p}$ $<0,0001$ ) (Tabelul 2). Mediana numărului de limfocite CD4 a fost 483/ $\mu$ l (IQR 290, 646), iar a încărcăturii virale HIV în plasmă de $2,74 \log _{10}$ copii/ ml (IQR 1,27, 4,67).

Evaluarea gradului de fibroză hepatică s-a realizat la $82,1 \%(138 / 168)$ dintre pacienţi, aproape o treime dintre aceştia fiind identificaţi cu fibroză hepatică avansată (27,5\%). Încărcătura virală VHC în plasmă s-a realizat pentru jumătate dintre pacienţii evaluaţi $(50,0 \%, 84 / 168)$, fiind detectabilă pentru 80.9\% (68/84). Pacienţii coinfectaţi HIV/VHC au avut viremia VHC semnificativ mai mare $(\mathrm{p}=$ 0.047 ) şi au asociat mai frecvent coinfecţie cu virusul hepatitic B (Tabelul 2).

În cadrul pachetului de lucru HepEd, 3 cursuri VHC cu informaţii actualizate despre managemen- tul hepatitei cronice $\mathrm{C}$ au fost organizate de echipa HepCare şi au participat 241 de pacienţi cu hepatită C. Au fost realizate şi împărţite broşuri şi pliante cu informaţii de bază privind epidemiologia şi tratamentul infecţiei cu VHC la pacienţii din populaţiile la risc.

La şedinţele de sprijin de la egal la egal, au participat 64 de pacienţi infectaţi cu HIV / VHC, ca parte a pachetului de lucru HepFriend.

24 de pacienţi au iniţiat tratament cu agenţi antivirali direcţi, dintre care 17 erau coinfectaţi HIV. 22 de pacienţi au obţinut răspuns viral susţinut, iar 2 au fost nonresponderi (utilizatori de droguri injectabile cu infecţie HIV, la care s-a identificat genotip $3 \mathrm{VHC}$, ce au primit tratament cu regim nonpangenotipic). 
TABELUL 2. Rezultatele investigațiilor paraclinice - comparație în funcție de statusul infecției HIV

\begin{tabular}{|c|c|c|c|c|c|}
\hline & & $\begin{array}{c}\text { Total } \\
\mathrm{n}=168\end{array}$ & $\begin{array}{c}\text { HIV (+) } \\
n=70\end{array}$ & $\begin{array}{c}\operatorname{HIV}(-) \\
n=98\end{array}$ & valoare $p$ \\
\hline \begin{tabular}{|l|} 
ALT \\
$(\mathrm{UI} / \mathrm{I})$ \\
\end{tabular} & $\begin{array}{c}\text { mediana } \\
(\mathrm{IQR})\end{array}$ & $\begin{array}{c}63 \\
(40,98) \\
\end{array}$ & $\begin{array}{c}65 \\
(43,100)\end{array}$ & $\begin{array}{c}58 \\
(34,97)\end{array}$ & 0,866 \\
\hline $\begin{array}{l}\text { Hemoglobină } \\
(\mathrm{g} / \mathrm{dl})\end{array}$ & $\begin{array}{c}\text { mediana } \\
(\mathrm{IQR})\end{array}$ & $\begin{array}{c}14,1 \\
(12,9,15,3) \\
\end{array}$ & $\begin{array}{c}13,7 \\
(12,5,14,9) \\
\end{array}$ & $\begin{array}{c}15,0 \\
(13,6,15,7) \\
\end{array}$ & 0,080 \\
\hline $\begin{array}{l}\text { Trombocite*10 } \\
(/ \mu \mathrm{l})\end{array}$ & $\begin{array}{c}\text { mediana } \\
(\mathrm{IQR})\end{array}$ & $\begin{array}{c}224 \\
(174,261)\end{array}$ & $\begin{array}{c}225 \\
(167,257)\end{array}$ & $\begin{array}{c}215 \\
(188,261)\end{array}$ & 0,640 \\
\hline Ag HBs pozitiv & $\mathrm{n}(\%)$ & $\begin{array}{c}13 \\
(7,7) \\
\end{array}$ & $\begin{array}{c}9 \\
(12,8) \\
\end{array}$ & $\begin{array}{c}4 \\
(4,0) \\
\end{array}$ & 0,011 \\
\hline $\begin{array}{l}\text { Gradul de fibroză hepatică } \\
\text { (Scor METAVIR) }\end{array}$ & $\begin{array}{c}\text { mediana } \\
(I Q R)\end{array}$ & $\begin{array}{c}7,0 \\
(5,4,9,3)\end{array}$ & $\begin{array}{c}7,0 \\
(6.0,9.5)\end{array}$ & $\begin{array}{c}7,0 \\
(5.3,9.3)\end{array}$ & 0,372 \\
\hline $\begin{array}{l}\text { ARN-VHC } \\
\left(\log _{10} \mathrm{UI} / \mathrm{I}\right)\end{array}$ & $\begin{array}{l}\text { mediana } \\
\text { (IQR) }\end{array}$ & $\begin{array}{c}6,11 \\
(5,48,6,52)\end{array}$ & $\begin{array}{c}6,30 \\
(5,77,6,66)\end{array}$ & $\begin{array}{c}5,50 \\
(5,16,5,88) \\
\end{array}$ & 0,047 \\
\hline
\end{tabular}

\section{DISCUȚII}

HepCare Europe este primul proiect care se adresează pacienţilor ce provin din populaţiile marginalizate din ţara noastră. Scopul acestui proiect a fost implementarea unui model de îngrijiri VHC, bazat pe servicii medicale primare şi secundare integrate (5). Spitalul „Victor Babeş“ din Bucureşti a fost implicat în toate pachetele de lucru ale acestui proiect.

Screening-ul VHC s-a realizat în locuri des frecventate de pacienţii din populaţiile cheie, cum ar fi adăposturile de noapte, centrele de tratament de substituţie cu metadonă, penitenciare sau alte unităţi medicale. Medicii de familie responsabili pentru fiecare din aceste centre de screening s-au implicat activ în testarea $\mathrm{VHC}$, alături de membrii echipei HepCare si de personalul ONG-urilor partenere. Pacienţii cu rezultat pozitiv au fost luaţi în evidenţă la Spitalul „Victor Babeş“ din Bucureşti, beneficiind astfel de servicii medicale integrate.

Pacienţii cu comportament la risc, în mod special utilizatorii de droguri injectabile, reprezintă o provocare majoră pentru sistemul de sănătate din România, din cauza particularităţilor multiple, medicale, sociale şi economice, pe care le asociază (5). Infecţia HIV şi virusul hepatitic C s-au răspândit rapid printre utilizatorii de droguri injectabile din România, pe fondul evoluţiei necontrolate a drogurile ilegale, dominată de creșterea semnificativă a consumului de droguri psihostimulante noi. Deoarece acestea erau mai uşor accesibile, un număr mare de consumatori au încercat să scape de adicţia la opioide prin switch-ul la etnobotanice, dar au eşuat, devenind dependenţi de ambele tipuri de droguri (3). Substanţele psihostimulante noi sunt derivate de catinone şi asociază efecte psihoactive similare celor produse de amfetamine. Sunt mai ieftine comparativ cu opioidele, dar, pentru că necesită multiple administrări pe zi, din motive economice, consumatorii preferă să utilizeze echipament nesteril de injectare, fapt ce a determinat răspândirea necontrolată a infecţiilor virale parenterale printre utilizatorii de droguri injectabile din România $(3,7)$.

Profilul pacienţilor testaţi pentru VHC în cadrul Proiectului HepCare Europe este al unui tânăr de sex masculin, utilizator de droguri injectabile, cu multiple comportamente la risc (abuz de alcool, istoric de detenţie, lipsa locuinţei).

Pacienţii din grupele vulnerabile, cu rezultat VHC pozitiv, au întâmpinat numeroase bariere sociale în încercarea de a accesa serviciile medicale. O parte dintre ei erau fără locuinţă, încarceraţi, nu aveau documente de identitate sau asigurare de sănătate. Procesul de obţinere a acestor documente este foarte complicat şi un număr important de pacienţi au fost pierduţi din evidenţă (3). Au fost, de asemenea, probleme în procesul de luare în evidenţă a pacienţilor încarceraţi, deoarece legile actuale din România nu permit evaluarea lor în spital în perioada detenţiei. Alţi pacienţi nu au respectat programările la spital, iar contactarea lor a fost dificilă (nu au răspuns la telefon, au schimbat numărul de telefon etc.). Asistenţii sociali din cadrul ONG-urilor au facilitat achiziţionarea documentelor pentru persoanele fără adăpost şi cărţi de identitate pentru ca aceste persoane să poată fí incluse în Programul naţional de tratament cu VHC. 
Aproape jumătate dintre pacienţii evaluaţi la Spitalul „Victor Babeş“ în cadrul Proiectului HepCare Europe au fost coinfectaţi HIV, iar câţiva dintre ei au fost infectaţi şi VHB. Infecţia HIV a fost mai frecvent asociată cu utilizarea de droguri etnobotanice, utilizarea de ace la comun, coinfecţie VHB şi încărcătură virală VHC mai mare în plasmă.

Tratamentul DAA a fost iniţiat la un număr mic de pacienţi înrolaţi în proiect, din cauza numeroaselor restricţii medicale şi sociale existente în ţara noastră. Stigma este un fenomen încă larg răspândit în România, un număr mare de pacienţi evitând să acceseze serviciile medicale din teama că vor fi respinşi. $\mathrm{Cu}$ toate acestea, coinfecţia HIV/VHC nu a fost o problemă pentru tratamentul pacienţilor înrolaţi în baza noastră de date. Toţi au fost foarte entuziaşti să iniţieze terapia şi au fost aderenţi la tratament.

Tratamentul cu agenţi antivirali direcţi (DAA) a fost recent introdus în România (2015), iniţial cu numeroase restricţii medicale (puţine regimuri terapeutice, foarte scumpe, disponibile numai la pacienţi cu grad avansat de fibroză hepatică). Ulterior, începând din septembrie 2018, tratamentul interferon-free a devenit disponibil tuturor pacienţilor cu fibroză cel puţin F1 şi viremie VHC detectabilă. În aceste condiţii, un număr redus de pacienţi diagnosticaţi cu VHC şi evaluaţi în cadrul Proiectului HepCare au fost eligibili pentru tratament. Protocolul Naţional de tratament VHC din România a fost recent actualizat şi în curând toate aceste bariere vor fi eliminate.

O altă problemă cu care s-a confruntat echipa HepCare a fost absenţa regimurilor terapeutice pangenotipice, în condiţiile în care genotiparea VHC înainte de iniţierea tratamentului nu se efectuează de rutină în România. Utilizarea drogurilor pe cale injectabilă a favorizat apariţia unor genotipuri VHC noi pe teritoriul ţării noastre, diferite de cel prevalent local (1b). Acestea $(1 \mathrm{a}, 3,4)$ sunt asociate cu fibroză hepatică accelerată, necesită anumite regimuri DAA şi răspund mai greu la tratament $(4,8)$. În aceste condiţii, 2 pacienţi din lotul tratat în cadrul proiectului nu au obţinut răspuns viral susţinut. Genotiparea efectuată după eşecul terapeutic a evidenţiat genotipul 3 în ambele cazuri. Totuşi, considerăm că tratamentul a 22 de pacienţi cu infecţie VHC, dintre care un număr mare prezintă şi HIV, reprezintă un prim succes şi un început promiţător în procesul de eliminare a hepatitei cronice cu virus $\mathrm{C}$ la pacienţii din grupele vulnerabile din ţara noastră.

Estimarea rentabilităţii implementării modelului este încă în curs de evaluare.

Utilizatorii de droguri injectabile care au fost diagnosticaţi cu hepatită C şi evaluaţi în cadrul Proiectului HepCare, dar care nu au fost eligibili pentru tratament până la finalul anului 2019, vor putea beneficia de tratament în viitorul apropiat, datorită noilor reglementări ale Protocolului Naţional de tratament VHC, reglementări ce au ca scop îndepărtarea tuturor barierelor medicale.

\section{CONCLUZII}

Eliminarea VHC va fi posibilă numai dacă pacienţii ce provin din populaţiile vulnerabile vor fi vindecaţi. Din nefericire, România deţine un număr mare de pacienţi cu comportamente la risc ce întâmpină numeroase bariere în încercarea de a accesa serviciile medicale adecvate. Microeliminarea VHC la pacienţii din populaţiile cheie reprezintă un pas deosebit de important în procesul de eliminare VHC la nivel mondial.

Modelul proiectului HepCare Europe implementat la Spitalul „Victor Babeş““ din Bucureşti s-a dovedit a fi eficient, motiv pentru care considerăm că poate fi implementat pe scară mult mai largă, chiar la nivel naţional.

Conflict of interest: none declared Financial support: none declared

\section{BIBLIOGRAFIE}

1. Gheorghe L, Sporea I, lacob S, Sirli R, Trifan A, Dobru D et al. Position paper on treatment of hepatitis $C$ in Romania, 2017. Part one. Journal of Gastrointestinal and Liver Diseases 2017; 26(2):171-81.

2. Esteban JI, Sauleda S, Quer J. The changing epidemiology of hepatitis $C$ virus infection in Europe. Journal of Hepatology. 2008; 48(1):148-62.

3. Oprea C, lanache I, Calistru PI, Nica M, Ruta S, Smith C et al. Increasing incidence of HIV-associated tuberculosis in Romanian injecting drug users. HIV medicine. 2018; 19(5):316-23.

4. Ruta S, Sultana C, Oprea C, Vagu C, Ceausu E, Cernescu C. HCV non-1b genotypes in injecting drug users from Romania. Journal of Infection in Developing Countries. 2016; 10(5):523-7. 
5. Swan D, Cullen W, Macias J, Oprea C, Story A, Surey J et al. HepCare Europe - bridging the gap in the treatment of hepatitis $C$ : Study protocol. Expert Review of Gastroenterology \& Hepatology. 2018; 12(3):303-14.

6. Avramovic G, Oprea C, Surey J, Story A, Macias J, Cullen W et al. HepCheck: Characteristics of the patient population with active infection as defined by HCV RNA. International Journal of Infectious Diseases (official publication of the International Society for Infectious Diseases). 2019.
7. lanache I, Calistru P, Tardei G, Ruta S, Oprea C. Late presentation in HIV-infected injecting drug users - a huge challenge for the Romanian health-care system. Romanian Journal of Legal Medicine. 2016; 24(2):122-7.

8. McPhee F. Developments in the treatment of HCV genotype 3 infection. Expert Review of Anti-infective Therapy. 2019; 17(10):775-85. 